Author's Conrtibution

A - Study Design

B - Data Collection

C - Statistical Analysis

D - Data Interpretation

E - Manuscript Preparation

$F$ - Literature Search

$\mathrm{G}$ - Funds Collection

\section{Effects of Interval Training of Maximal Effort Intensity*}

\author{
Henryk Norkowski ${ }^{1(A, B, D, F)}$, Anna Kuder ${ }^{1(A, D, G)}$, \\ Tadeusz Huciński ${ }^{2(A, D, F)}$, Stanisław Przybylski ${ }^{2(B, D, E)}$ \\ 1 Józef Piłsudski University of Physical Education in Warsaw, Poland \\ 2 Jedrzej Sniadecki Academy of Physical Education and Sport \\ in Gdansk, Poland
}

Key words: untrained men, interval training, cycloergometer, maximal effort intensity

\begin{abstract}
Background: The purpose of this study was to determine changes in anaerobic capacity at $100 \%$ physical effort intensity in the examined people.

Materials and methods:

12 male students from the University of Physical Education in Warsaw were subject to these examinations. The average age was 23.6 years, mean body height $178.7 \mathrm{~cm}$, and body mass $80.6 \mathrm{~kg}$. The experiment was carried out from 7th January to 8th March 2008. The experiment (one group) was carried out in two stages. The first stage had 25 training units on a cycloergometer within 5 weeks. The second stage was connected with controlling the obtained results for 3 consecutive weeks after completing the training. An individual load consisted of 6 efforts (10s work, 60 s rest) performed with intensity at $100 \%$ of the individual's maximum power in consecutive test trials. All training and test trials were performed by means of the Monark 824E (Sweden) cycloergometer linked with a PC computer, MCE v.4.0 software.

Results: The results revealed that effort stimuli made significant changes in mechanical work, maximum power, time of achieving maximum power after a fourweek period of exercises on a cycloergometer.

Conclusions: The used training loads significantly affected the improvement of the results in terms of mechanical work, maximum power, time of developing and maintaining it. The dynamics of changes of anaerobic capacity parameters, after completing the training, may be used as a factor of reliable steering the training loads in terms of intensity.
\end{abstract}

DOI: 10.2478/v10131-010-0003-z

$\begin{array}{lrlr}\text { Word count: } & 2382 & & \\ \text { Tables: } & 4 & \text { Received: } & \text { July } 2009 \\ \text { Figures: } & 0 & \text { Accepted: } & \text { June } 2010 \\ \text { References: } & 29 & \text { Published: } & \text { September } 2010\end{array}$

Address for correspondence

Prof. Henryk Norkowski, University of Physical Education, Department of Team Sports Games, 00-968 Warsaw 45, Poland, ul. Marymoncka 34 Phone: +4822/ 864-09-73 E-mail: henryk.norkowski@awf.edu.pl

\footnotetext{
* The paper financed by MNiSW (Polish Ministry of Science and Higher Education) Subject no. BW - I.26
} 


\section{Introduction}

Athletes, coaches and scientists who deal with sport training more and more shift the limits of human adaptation to training loads in order to succeed in their sports. The problem is connected with decreasing training loads just prior to contest. In many sports, the best results are observed with decreasing the performed training loads a short time before the competition $[1,2,3,4,5]$. The period of decreasing loads is commonly called "taper". Within "taper" the following variables are considered: duration of the training sessions, frequency and intensity. Intensity, in terms of anaerobic capacity, makes most problems in a coach's work. The intensity of training loads is called a qualitative variable and mostly affects training results. Research on high intensity efforts which determine anaerobic capacity leads to optimisation of the training process. According to many scientists and coaches, interval training is the basic method of developing adaptation changes in anaerobic capacity $[6,7,8,9,10,11]$.

The purpose of this work was to assess the results of mechanical work, maximum power, the time of maximum power and maintaining it in the consecutive effort trials at the intensity of $100 \%$ of individual capacity within the examined group.

\section{Material and methods}

12 students (men) from the University of Physical Education in Warsaw were subject to these examinations. Their physical activities were limited to the obligatory practical classes. The average age was 23.6 years, mean body height $178.7 \mathrm{~cm}$, and body mass $80.6 \mathrm{~kg}$. The experiment was carried out from 7th January to 8th March 2008. An 8-week experiment was accepted by the Senate Commission of Ethics for Scientific Research at the University of Physical Education in Warsaw. The participants were advised on the purpose of the training, its methodics, and they submitted their written consent.

An experiment (one group) was carried out in two stages. The first stage had 25 training units on a cycloergometer within 5 weeks. The second stage was connected with controlling the obtained results for 3 consecutive weeks after completing the training. An individual load consisted of 6 efforts (10s work, 60s rest) performed with intensity at $100 \%$ of the individual's maximum power in consecutive test trials. Prior to the experiment and at the end of a consecutive week cycle (each 5 th training) a test was carried out -8 trials for 10 s each with 60 s intervals. The training was completed after 5 weeks, when no significant differences in the analyzed parameters were observed during two consecutive tests. All training and test trials were performed by means of the Monark 824E (Sweden) cycloergometer linked with a PC computer, MCE v.4.0 software which enabled setting up freely the performed work (J), time of effort [s] or the number of turns of the fly-wheel (the turn detectors fixed to the cycloergometer fly-wheel). During one turn on pedals the fly-wheel makes 3.7 turns which is equal to a distance of $6 \mathrm{~m}$ (measurement error of one turn time $=1 \mathrm{~ms})$. The cycloergometer load was $0.075 \mathrm{kp} \mathrm{kg}^{-1}$.

The values of mechanic work $(\mathrm{J} / \mathrm{kg})$ were analyzed as well as the maximum power $(\mathrm{W} / \mathrm{kg})$ performed in each repetition of the test effort. The analyzed data has been presented as the mean values and the standard deviations $(M \pm S D)$. Intrinsic differences between mean values were estimated by means of the ANOVA variant analysis with repeated measurements, and group variability was determined by the NIR test, assuming value levels $p<0.05$ as significant. All calculations were carried out by the STATISTICA ${ }^{\text {TM }}$ (v. 5.5. Stat Soft. USA).

\section{Results}

\section{Mechanical work}

The assessment of the mean values of mechanical work during effort tests at the beginning and after 5 weeks of the experiment revealed a statistically significant increase in the analyzed parameter. The changes in consecutive repetitions ranged from $11-22 \%$, and from the fourth 
effort increased up to the highest value (21.84\%) at the last one (8th effort). Analyzing the dynamics of decrease in the values of mechanical work performed in consecutive effort tests, statistically significant differences were not observed, and a decrease in mean values of that parameter was at the level of $4-8 \%$. Comparing mean values of mechanical work at the beginning of the experiment and after 3 weeks from completing the training, it was ascertained that at each repetition, mean values of that parameter were higher by $6-11 \%$ than the initial values (Table 1).

\section{Maximum power}

Comparing maximum power values developed in consecutive repetitions of the effort tests before and after 5 weeks of the training, there was a statistically significant increase in the values of the analyzed parameter. It ranged between $13-20 \%$ and was increasing in the consecutive repetitions up to $19.49 \%$ in the last $\left(8^{\text {th }}\right)$ test. Analyzing the mean values of maximum power developed in the consecutive repetitions after three weeks of the interval, no statically intrinsic differences were observed in comparison to the maximal values, and a decrease in the value of that parameter ranged from 6 to

Tab. 1. Differentiation of mean values of mechanical work $[\mathrm{J} / \mathrm{kg}]$ in repetitions of the test effort before training, after 5 weeks of interval training and after 3 weeks without training

\begin{tabular}{|c|c|c|c|c|c|c|c|c|c|}
\hline $\begin{array}{l}\text { Measurement } \\
\text { periods }\end{array}$ & $n=12$ & 1 effort & 2 effort & 3 effort & 4 effort & 5 effort & 6 effort & 7 effort & 8 effort \\
\hline before interval training & $\begin{array}{l}M \\
S D\end{array}$ & $\begin{array}{r}96.33 \\
\pm 8.04\end{array}$ & $\begin{array}{l}95.31 \\
\pm 6.80\end{array}$ & $\begin{array}{l}89.67 \\
\pm 5.82\end{array}$ & $\begin{array}{l}86.26 \\
\pm 5.16\end{array}$ & $\begin{array}{l}83.77 \\
\pm 5.78\end{array}$ & $\begin{array}{l}81.63 \\
\pm 6.90\end{array}$ & $\begin{array}{r}79.89 \\
\pm 6.90\end{array}$ & $\begin{array}{l}77.51 \\
\pm 6.90\end{array}$ \\
\hline $\begin{array}{l}\text { after } 5 \text { weeks of } \\
\text { training }\end{array}$ & $\begin{array}{l}M \\
S D\end{array}$ & $\begin{array}{l}111.03^{*} \\
\pm 6.66\end{array}$ & $\begin{array}{l}106.41^{*} \\
\pm 5.59\end{array}$ & $\begin{array}{l}102.30^{*} \\
\pm 5.54\end{array}$ & $\begin{array}{l}100.23^{*} \\
\pm 6.96\end{array}$ & $\begin{array}{l}99.44^{*} \\
\pm 7.32\end{array}$ & $\begin{array}{l}97.91^{*} \\
\pm 7.07\end{array}$ & $\begin{array}{l}95.90^{*} \\
\pm 7.07\end{array}$ & $\begin{array}{l}94.44^{*} \\
\pm 7.07\end{array}$ \\
\hline difference ${ }^{* *}$ & $\%$ & +15.25 & +11.64 & +14.08 & +16.19 & +18.71 & +19.95 & +20.04 & +21.84 \\
\hline $\begin{array}{c}\text { after } 3 \text { weeks without } \\
\text { training }\end{array}$ & $\begin{array}{l}M \\
S D\end{array}$ & $\begin{array}{l}103.64 \\
\pm 3.98\end{array}$ & $\begin{array}{l}101.29 \\
\pm 3.76\end{array}$ & $\begin{array}{l}98.02^{*} \\
\pm 3.28\end{array}$ & $\begin{array}{l}94.48^{*} \\
\pm 4.13\end{array}$ & $\begin{array}{l}91.59^{*} \\
\pm 4.70\end{array}$ & $\begin{array}{l}98.57^{*} \\
\pm 4.85\end{array}$ & $\begin{array}{l}88.04^{*} \\
\pm 5.58\end{array}$ & $\begin{array}{l}87.07^{*} \\
\pm 6.27\end{array}$ \\
\hline difference ${ }^{* *}$ & $\%$ & +7.05 & +5.90 & +8.52 & +8.70 & +8.54 & +8.86 & +9.26 & +10.98 \\
\hline difference ${ }^{* * *}$ & $\%$ & -6.65 & -4.81 & -4.18 & -5.74 & -7.89 & -8.52 & -8.20 & -7.81 \\
\hline
\end{tabular}

* significant difference $(p<0.05)$ in relation to the initial level

** difference in relation to the initial level

*** difference in relation to the maximal level

Tab. 2. Differentiation of mean values of the maximal power [W/kg] in repetitions of the best effort before training, after 5 weeks of interval training and after 3 weeks without training

\begin{tabular}{|c|c|c|c|c|c|c|c|c|c|}
\hline $\begin{array}{l}\text { Measurement } \\
\text { periods }\end{array}$ & $n=12$ & 1 effort & 2 effort & 3 effort & 4 effort & 5 effort & 6 effort & 7 effort & 8 effort \\
\hline before interval training & $\begin{array}{l}M \\
S D\end{array}$ & $\begin{array}{r}11.06 \\
\pm 1.03\end{array}$ & $\begin{array}{r}10.75 \\
\pm 0.63\end{array}$ & $\begin{array}{c}10.54 \\
\pm 10.78\end{array}$ & $\begin{array}{l}10.14 \\
\pm 0.54\end{array}$ & $\begin{array}{c}9.79 \\
\pm 0.62\end{array}$ & $\begin{array}{c}9.61 \\
\pm 0.73\end{array}$ & $\begin{array}{c}9.49 \\
\pm 0.73\end{array}$ & $\begin{array}{c}9.08 \\
\pm 0.73\end{array}$ \\
\hline $\begin{array}{l}\text { after } 5 \text { weeks of } \\
\text { training }\end{array}$ & $\begin{array}{l}M \\
S D\end{array}$ & $\begin{array}{l}12.51 \\
\pm 0.81\end{array}$ & $\begin{array}{r}12.39 \\
\pm 0.57\end{array}$ & $\begin{array}{l}12.12^{*} \\
\pm 0.56\end{array}$ & $\begin{array}{l}11.85^{*} \\
\pm 0.56\end{array}$ & $\begin{array}{l}11.54^{*} \\
\pm 0.62\end{array}$ & $\begin{array}{l}11.46^{*} \\
\pm 0.68\end{array}$ & $\begin{array}{l}11.16^{*} \\
\pm 0.68\end{array}$ & $\begin{array}{l}10.85^{*} \\
\pm 0.68\end{array}$ \\
\hline difference $^{* *}$ & $\%$ & +13.11 & +15.25 & +15.01 & +16.80 & +17.80 & +19.30 & +17.59 & +19.49 \\
\hline $\begin{array}{c}\text { after } 3 \text { weeks without } \\
\text { training }\end{array}$ & $\begin{array}{l}M \\
S D\end{array}$ & $\begin{array}{l}11.79^{*} \\
\pm 0.57\end{array}$ & $\begin{array}{l}11.60^{*} \\
\pm 0.60\end{array}$ & $\begin{array}{l}11.25^{*} \\
\pm 0.45\end{array}$ & $\begin{array}{l}10.94^{*} \\
\pm 0.43\end{array}$ & $\begin{array}{l}10.69^{*} \\
\pm 0.53\end{array}$ & $\begin{array}{l}10.47^{*} \\
\pm 0.51\end{array}$ & $\begin{array}{l}10.29^{*} \\
\pm 0.58\end{array}$ & $\begin{array}{l}10.21^{*} \\
\pm 0.53\end{array}$ \\
\hline difference ${ }^{* *}$ & $\%$ & +6.16 & +7.33 & +6.31 & +7.31 & +8.42 & +8.21 & +7.77 & +11.07 \\
\hline difference ${ }^{* * *}$ & $\%$ & -5.75 & -6.37 & -7.18 & -7.68 & -7.37 & -8.64 & -7.80 & -5.90 \\
\hline
\end{tabular}

* significant difference $(p<0.05)$ in relation to the initial level

${ }^{* *}$ difference in relation to the initial level

*** difference in relation to the maximal level 
$9 \%$. A comparison of the mean values of maximum power developed at the beginning of the experiment and after three weeks from the completion of the training revealed that at each repetition mean values of that parameter were statistically higher by $6-11 \%$ than the initial values (Table 2 ).

\section{Developing time of maximum power}

Comparing the mean time of developing maximum power during the same repetitions of the contest effort before the training and after five weeks of the experiment, a varied increase in the value of that parameter was observed (range $0-7 \%$ ), but the differences were not statistically significant. The comparison of the maximum value of the parameter with the results obtained after three weeks from completing the experiment revealed that at each repetition the time needed for developing maximum power was prolonged. The range of changes at particular repetitions, was different by $14-30 \%$. A similar situation was seen while comparing the mean values of the parameter in relation to the initial level because it was ascertained that after three weeks' interval, the mean time of developing maximum power at particular repetitions of the effort was prolonged from 14 to $22 \%$ (Table 3 ).

Tab. 3. Differentiation of mean values of developing time of the maximal power in repetitions of the test effort before training, after 5 weeks of interval training and after 3 weeks without training

\begin{tabular}{|c|c|c|c|c|c|c|c|c|c|}
\hline $\begin{array}{l}\text { Measurement } \\
\text { periods }\end{array}$ & $n=12$ & 1 effort & 2 effort & 3 effort & 4 effort & 5 effort & 6 effort & 7 effort & 8 effort \\
\hline before interval training & $\begin{array}{l}M \\
S D\end{array}$ & $\begin{array}{c}4.18 \\
\pm 0.53\end{array}$ & $\begin{array}{c}3.98 \\
\pm 0.53\end{array}$ & $\begin{array}{c}3.56 \\
\pm 0.37\end{array}$ & $\begin{array}{c}3.69 \\
\pm 0.60\end{array}$ & $\begin{array}{c}3.48 \\
\pm 0.45\end{array}$ & $\begin{array}{c}3.66 \\
\pm 0.83\end{array}$ & $\begin{array}{c}3.66 \\
\pm 0.83\end{array}$ & $\begin{array}{c}3.66 \\
\pm 0.83\end{array}$ \\
\hline $\begin{array}{l}\text { after } 5 \text { weeks of } \\
\text { training }\end{array}$ & $\begin{array}{l}M \\
S D\end{array}$ & $\begin{array}{l}3.88 \\
\pm 0.3\end{array}$ & $\begin{array}{c}3.71 \\
\pm 0.37\end{array}$ & $\begin{array}{c}3.49 \\
\pm 0.56\end{array}$ & $\begin{array}{c}3.77 \\
\pm 0.74\end{array}$ & $\begin{array}{c}3.43 \\
\pm 0.66\end{array}$ & $\begin{array}{c}3.63 \\
\pm 0.68\end{array}$ & $\begin{array}{c}3.63 \\
\pm 0.68\end{array}$ & $\begin{array}{c}3.63 \\
\pm 0.68\end{array}$ \\
\hline difference ${ }^{\star \star}$ & $\%$ & -7.63 & -4.49 & -2.00 & +2.31 & -1.50 & -0.90 & -0.90 & -0.90 \\
\hline $\begin{array}{c}\text { after } 3 \text { weeks without } \\
\text { training }\end{array}$ & $\begin{array}{l}M \\
S D\end{array}$ & $\begin{array}{c}4.95 \\
\pm 0.24\end{array}$ & $\begin{array}{c}4.40 \\
\pm 0.40\end{array}$ & $\begin{array}{c}4.34 \\
\pm 0.37\end{array}$ & $\begin{array}{c}4.27 \\
\pm 0.41\end{array}$ & $\begin{array}{c}4.46 \\
\pm 0.49\end{array}$ & $\begin{array}{c}4.22 \\
\pm 0.52\end{array}$ & $\begin{array}{c}4.33 \\
\pm 0.47\end{array}$ & $\begin{array}{c}4.56 \\
\pm 0.80\end{array}$ \\
\hline difference ${ }^{* *}$ & $\%$ & +15.56 & +11.59 & +17.97 & +13.58 & +21.97 & +13.27 & +15.47 & +19.74 \\
\hline difference ${ }^{* * *}$ & $\%$ & +27.58 & +18.28 & +24.36 & +13.26 & +30.03 & +16.25 & +19.28 & +25.62 \\
\hline
\end{tabular}

* significant difference $(p<0.05)$ in relation to the initial level

** difference in relation to the initial level

*** difference in relation to the maximal level

Tab. 4. Differentiation of mean values of developing time of the maximal power in repetitions of the test effort before training, after 5 weeks of interval training and after 3 weeks without training

\begin{tabular}{|c|c|c|c|c|c|c|c|c|c|}
\hline $\begin{array}{l}\text { Measurement } \\
\text { periods }\end{array}$ & $n=12$ & 1 effort & 2 effort & 3 effort & 4 effort & 5 effort & 6 effort & 7 effort & 8 effort \\
\hline before interval training & $\begin{array}{l}M \\
S D\end{array}$ & $\begin{array}{c}2.36 \\
\pm 0.64\end{array}$ & $\begin{array}{c}2.31 \\
\pm 0.58\end{array}$ & $\begin{array}{r}1.89 \\
\pm 0.48\end{array}$ & $\begin{array}{c}1.71 \\
\pm 0.69\end{array}$ & $\begin{array}{c}1.66 \\
\pm 0.67\end{array}$ & $\begin{array}{c}1.52 \\
\pm 0.81\end{array}$ & $\begin{array}{r}1.52 \\
\pm 0.81\end{array}$ & $\begin{array}{c}1.47 \\
\pm 0.81\end{array}$ \\
\hline $\begin{array}{l}\text { after } 5 \text { weeks of } \\
\text { training }\end{array}$ & $\begin{array}{l}M \\
S D\end{array}$ & $\begin{array}{l}3.10^{*} \\
\pm 0.82\end{array}$ & $\begin{array}{l}3.06^{*} \\
\pm 0.50\end{array}$ & $\begin{array}{l}2.81^{*} \\
\pm 0.58\end{array}$ & $\begin{array}{l}2.58^{*} \\
\pm 0.53\end{array}$ & $\begin{array}{l}2.42^{*} \\
\pm 0.58\end{array}$ & $\begin{array}{l}2.32^{*} \\
\pm 0.61\end{array}$ & $\begin{array}{l}2.05^{*} \\
\pm 0.61\end{array}$ & $\begin{array}{l}2.19^{*} \\
\pm 0.61\end{array}$ \\
\hline difference $^{* *}$ & $\%$ & +31.35 & +32.29 & +48.67 & +50.88 & +45.78 & +52.63 & +34.86 & +48.97 \\
\hline $\begin{array}{c}\text { after } 3 \text { weeks without } \\
\text { training }\end{array}$ & $\begin{array}{l}M \\
S D\end{array}$ & $\begin{array}{c}2.50 \\
\pm 0.59\end{array}$ & $\begin{array}{c}2.25 \\
\pm 0.60\end{array}$ & $\begin{array}{c}1.97 \\
\pm 0.66\end{array}$ & $\begin{array}{r}1.98 \\
\pm 0.58\end{array}$ & $\begin{array}{c}1.81 \\
\pm 0.52\end{array}$ & $\begin{array}{r}1.80 \\
\pm 0.39\end{array}$ & $\begin{array}{r}1.88 \\
\pm 0.44\end{array}$ & $\begin{array}{c}1.68 \\
\pm 0.45\end{array}$ \\
\hline difference $^{\star *}$ & $\%$ & +5.60 & -2.67 & +4.06 & +13.64 & +8.29 & +15.56 & +19.15 & +12.50 \\
\hline difference ${ }^{* * *}$ & $\%$ & -19.35 & -26.47 & -29.87 & -23.26 & -25.21 & -22.41 & -16.10 & -23.29 \\
\hline
\end{tabular}

* significant difference $(p<0.05)$ in relation to the initial level

** difference in relation to the initial level

*** difference in relation to the maximal level 


\section{Time of maintaining the maximum power}

Comparing the mean values of the time of maintaining the maximum power during the experiment, a statistically significant increase in the parameter was ascertained in the range $31-53 \%$. Analyzing the level of value of the parameter after 3 weeks' interval it was ascertained that at each repetition the time of maintaining was reduced, and the range of changes was $16-30 \%$. Comparing the initial level of the parameter with the results after 3 weeks' interval one should emphasize that the mean time of maintaining the maximum power at particular repetitions was constantly longer and ranged from 3 to $6 \%$ (Table 4 ).

\section{Discussion}

A physiological response of the human system to physical effort depends on the increase in energetic demand related to that effort, and it differs individually. This difference is genetically determined and it is connected with adaptation efficiency of functional systems, organs, the biomechanical process as well as reserves of energetic substrates.

As it has already been said, the experimental problem is connected with finding how to decrease the training loads prior to contest (tapering). In many sports the best results achieved during competitions are connected with decreasing the training loads just before competitions. Among the considered variables there are: the duration, the frequency and the intensity of training sessions. Intensity creates most problems for coaches. First, an athlete's systems should acquire the optimal adaptational capacity and maintain it during the competition period, but without overtraining. Secondly, a proper balance between aerobic and anaerobic processes is required in particular sports. That balance should be acquired at the time of competitions. Knowledge, abilities and competence prove a coach's professionalism.

In this work, the authors have attempted to determine changes in anaerobic capacity, by means of assessing the effects of mechanical work, maximum power, time of maintaining the maximum power affected by effort at the intensity level of $100 \%$ of individual capacities within the examined group.

The results of the experiment, as have been presented in this paper, enabled us to ascertain that the training loads for 5 weeks were effective training stimuli, which probably affected adaptational changes in terms of anaerobic capacity. We say: probably, due to the fact that adaptational changes were not controlled, but only the effects of those changes were considered. In the consecutive effort trials the analysis of the presented results indicates the statistically significant improvement of the effects in mechanical work, maximum power, time of developing and maintaining it as well. Considering the fact that those examined students do not practice sport at competition level, the scale of the observed effects should be emphasized. A significant increase was observed in all examined parameters.

The views on the methods of shaping the adaptational changes in terms of anaerobic capacity differ in details. Many scientists and sport coaches believe that interval training is the basic method for shaping the mentioned changes $[6,7,8,9,10,11]$. Some authors recommended efforts performed in a series of 3,6 or 10 efforts with intervals $[6,12,13,14,15,16,17,18,19,20]$. Some of them say that the time of maximum effort should not be longer than 10sec. [8, 21,22,23,24].

Adaptational changes take place at the molecular level and they are connected with a synthesis of specific proteins for particular physical efforts [25,26,27]. Adaptational changes in anaerobic capacity manifest in increasing the activity and the quality of enzymes (ATPasis, myokinasis, creatine kinasis, glycolit) active in ATP resynthesis $[23,28,29]$. They also generate the quantity of energetic substrates in skeleton muscles cells.

Thus the problems of working out the methods of shaping anaerobic capacity (in details) is still open and calls for much more controlled experiments. 


\section{Conclusions}

The used training loads significantly affected the improvement of the results in terms of mechanical work, maximum power, time of developing and maintaining it.

The dynamics of changes of anaerobic capacity parameters after completing the training may be used as a factor of reliable steering the training loads in terms of intensity.

\section{References}

1. Johns RA, Houmard JA, Kobe RW, et al. Effects of taper on swim power, stroke distance and performance. Med Sci Sport Exer 1992;10(24):1141-1146.

2. Bompa TO. Periodization: theory and methodology of training. Champaign, II: Human Kinetics; 1999.

3. Costill DL, King DS, Thomas R, Hargreaves R. Effects of reduced training on muscular power in swimmers. Physician Sportsmed 1985;13:94-101.

4. Wilmore JH, Costill DL. Physiology of Sport and Exercise. 2nd ed. Champaign, II: Human Kinetics; 1999.

5. Maglischo EW. Swimming fastest. Champaign III.: Human Kinetics; 2003.

6. Balsom PD, Seger JY, Sjodin B, Ekblom B. Maximal-intensity intermittent exercise: effect of recovery duration. Int J Sport Med 1992;13:528-533.

7. Gibala MJ, McGee SL, Garnham AP, Howlett KF, Snow RJ, Hargreaves M. Brief intense interval exercise activates AMPK and p38 MAPK signaling and increases the expression of PGC-1 $\alpha$ in human skeletal muscle. $J$ Appl Physiol 2009;106(3):929-34.

8. Norkowski H. Struktura obciążeń wysiłkowych a efekty treningu przerywanego o maksymalnej intensywności [Structure of effort loads vs effects of interval training of maximal intensity]. Studia i Monografie nr 89. Warszawa: AWF; 2003 [in Polish].

9. Sozański H. Wytrzymałość [Endurance]. Trening 1992;1:239-261 [in Polish].

10. Sozański H, editor. Podstawy teorii treningu [Basics of training theory]. Warszawa: RCM- SKFiS, 1993 [in Polish].

11. Wołkow NI. Bioenergetyczne podstawy i ocena wytrzymałości [Bioenergetic basis and an assessment of endurance]. Sport Wyczynowy 1989;7-8:7-18 [in Polish].

12. Balsom PD, Gaitanos GC, Ekblom B, Sjodin B. Reduced oxygen availability during high intensity intermittent exercise impairs performance. Acta Physiol Scand 1999;152:279-285.

13. Norkowski H, Hubner-Woźniak E, Krawczyk K, Zghidi M. Wydolność beztlenowa młodych mężczyzn o różnym poziomie aktywności fizycznej [Anaerobic capacity in young men of a varied level of physical activity]. Roczniki Naukowe AWF w Warszawie 2004;43:119-128 [in Polish].

14. Norkowski H, Kłosowski M, Buśko K. Physiological responses to repeated bouts of anaerobic exercise. Phys Educ Sport 2002;46(supl. 1/1):576-578.

15. Klimek A. Fizjologiczne reakcje układu oddechowego podczas powtarzanych wysiłków fizycznych na tle wydolności aerobowej i anaerobowej dzieci i osób dorosłych [Physiological reactions of the respiratory system during repetitious physical efforts against a background of aerobic and anaerobic capacity in children and adults]. Studia i Monografie nr 28. Kraków: AWF; 2004 [in Polish].

16. Lakomy HKA, Lakomy J, Martin D, Nevill ME. Fatigue and the power-velocity relationship of muscle measured during cycling. J Sport Sci 1994;12:142.

17. Trzaskoma Z, Lipiński P. Maksymalna moc i maksymalna siła mięśni kończyn dolnych 16-18-letnich sportowców [Maximal force and maximal power of lower limbs in 16-18-year-old sportmen]. Biol Sport 1997;14(7):156-161 [in Polish].

18. Fidelus K, Ostrowska E, Tokarski T, Urbanik C. Zmiana siły i mocy mięśni kończyn dolnych pod wpływem treningu na cykloergometrze [Change in power and force of lower limbs under the influence of training on a cycloergometer]. Monografie AWF Poznań 1996;330:177-182 [in Polish].

19. Fidelus K, Mastalarz A, Ostrowska E, Urbanik C, Wychowańska M. Zmiana mocy i siły mięśniowej pod wpływem treningu skocznościowego [Change in power and force of muscles under the influence of jump training]. Monografie AWF Poznań 1996;330:171-176 [in Polish].

20. Fidelus K, Mastalarz A, Tokarski T. Spadek mocy w czasie ćwiczeń na równi pochyłej, ergometrze rowerowym i platformie dynamometrycznej [Drop in force during exercises on an inclined plane, a cycloergometer and a dynamometric platform]. Monografie AWF Poznań 1996;330:151-154 [in Polish].

21. Jaskólski A. Fizjologiczne przystosowanie do wysiłku oraz fizjologiczne podstawy treningu [Physiological adaptation to effort and the physiological basis of training]. In: Jaskólski A, editor. Podstawy fizjologii wysiłku fizycznego z zarysem fizjologii człowieka [Basics of physical effort physiology incl. the outline of human physiology]. Wrocław: AWF; 2002, 228-256 [in Polish].

22. Kubica R. Podstawy fizjologii pracy i wydolności fizycznej [Basics of physiology of work and physical capacity]. Kraków: AWF; 1999 [in Polish].

23. Linossier M, Denis C, Dormois D, Geyssant A, Lacour JR. Ergometric and metabolic adaptation to a 5-s sprint training programme. Eur J Appl Physiol 1993;67:408-414. 
24. Stupnicki R, Norkowski H. Index of anaerobic endurance in repeated maximal exercise bouts. Papers Anthropol 2001;10:280-287.

25. Millward DJ, Garlick PJ, James WPT, Nnanyelugo DO, Ryatt JS. Relationship between protein synthesis and RNA content in skeletal muscle. Nature 1973;241:204-205.

26. Seedorf U, Leberer E, Kirchbaum BJ, Pette D. Neural control of gene expression in skeletal muscle. Effects of chronic stimulation on lactate dehydrogenase isoenzymes and citrate synthase. Biochem J 1986;239:115-120.

27. Williams RS, Salmons S, Newsholme EA, Kaufman RE, Mellor J. Regulation of nuclear and mitochondrial gene expression by contractile activity in skeletal muscle. J Biol Chem 1986;261:376-380.

28. Costill DL. Zmiany w mięśniu szkieletowym podczas szybkościowego i wytrzymałościowego treningu pływackiego [Change in a skeletal muscle during speed and endurance training of swimmers]. Sport Wyczynowy 1979;8:43 [in Polish].

29. Roberts $A D$, Billeter $R$, Howald $H$. Anaerobic muscle enzyme changes after interval training. Int $J$ Sport Med 1982;3:18-21. 